\title{
BUILDING COALITIONS: Coalition Functioning
}

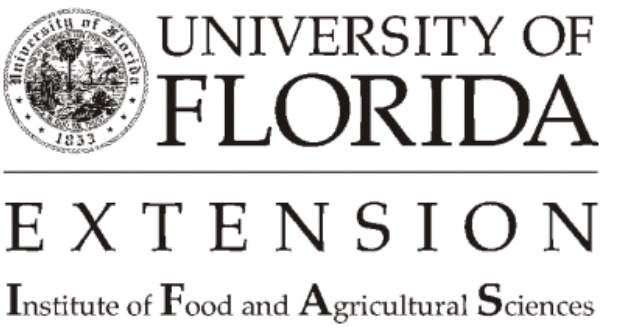




\section{A Committee in Disguise}

Starting and maintaining a coalition is no big mystery. It is similar to starting and maintaining a committee where there is a need and people interested in finding a solution. The United States started as a coalition of colonies with a need (problem) and people interested in finding a solution.

Though the functions of a committee and a coalition are very similar, the word "committee" may need to be avoided. Negative comments have often been made about committees. For example: "The camel is just a horse put together by a committee." The fewer committee meetings the better." "Too much of my day is used up in useless committees."

\section{Elements of Success}

- Common Goals - What is the expressed need (or "problem equals..") the group agrees is a priority. What is the desired change? These need to be understood by all involved.

- Communication - Use common language that everyone can understand. Avoid professional jargon. Each member needs to know what is expected. For example, minutes of meetings should be distributed to all members.

- $\quad$ Each Member is Important to the Coalition - Each participant should be able to perceive themselves as an important part of the whole, contributing to its success.

- Opportunity to Participate - Each member should have input into goals, methods and decisions, as well as discussion.

- Ownership - Feeling a part of the coalition and responsibility for some action is an important result of participating in the decision-making process.

- Delegation - Delegate to each entity a part they can control. That provides an opportunity for individual accomplishments as well as contributes to the overall success of the coalition.

- $\quad$ Efficient, Effective Meetings - Keep the meetings moving toward the agreed goals. Each should show progress toward the overall target(s) and participants should recognize this progress when they leave.

- Process and Pattern - Establish a format for conduct of meetings and decision-making early in the development of the coalition.

- Shared or Situational Leadership - It is important that many persons or groups share leadership responsibilities. 
While attention to group goals and objectives is essential, developing and maintaining committees and coalitions is also an interpersonal process. This requires close attention to group process and skills.

\section{Summary}

The principles that relate to effective coalition functioning coincide with the principles of effective committee functioning. 


\section{References}

Benard, Bonnie. "Collaboration Fosters Creative Problem Solving." Western Center News (March 1991)

Lippitt, Ronald and Jon Van Till, "Can We Achieve a Collaborative Community?," Journal of Voluntary Action Research (July-December 1981).

Lippitt, Ronald and Jon Vall Till, "Issues, Imperatives, Potentials," Journal of Voluntary Action Research (July-December 1981).

Schindler-Rainman, Eva, "Toward Collaboration-Risks We Need to Take," Journal of Volunteer Action Research (July-December 1981)

"Treatment: Building Child Service Partnerships," Children and Teens Today (December 1990)

\section{Authors}

Charles H. Bell, Associate Professor, District Specialist, 4-H, Ohio Cooperative Extension Service, The Ohio State University.

Penne Smith, County Extension Agent, 4-H, Community and Natural Resource Development, Chair, Ohio Cooperative Extension Service, The Ohio State University.

\section{(C) 1992 The Ohio State University}

This series on Coalition Building was developed by The Ohio Center For Action on Coalition Development for Family and High Risk Youth, Richard Clark, Ph.D., Director. It has been adapted for County Extension Faculty in Florida to facilitate work with local and regional organizations and groups such as non-profits, cooperatives, county extension associations, and others that might benefit from a plan for working together to achieve support for mutual goals.

This document is FY495, Part 3 of the 16 part series adapted for use in Florida by Elizabeth B. Bolton, Professor, Community Development and Lisa Guion, Assistant Professor, Program Planning and Evaluation; Department of Family, Youth and Community Sciences, Florida Cooperative Extension Service, Institute of Food and Agricultural Sciences, University of Florida, Gainesville, 32611-0310.

Reprinted with permission March, 1997. Revised April, 2002.

The Institute of Food and Agricultural Sciences is an equal opportunity/affirmative action employer authorized to provide research, educational information and other services only to individuals and institutions that function without regard to race, color, sex, age, handicap, or national origin. For information on obtaining other extension publications, contact your county Cooperative Extension Service office. 